legacy, weakening the power of the military over the civilian government and helping thousands of torture victims discuss and finally come to terms with their anguish.

Technically, the ruling yesterday is nothing more than a suspension of the charges and may be reversed if General Pinochet's health improves. But the former dictator, who wears a pacemaker, has diabetes and had several minor strokes in recent years. A week ago, he was admitted to a military hospital for treatment of diabetes, hypertension and circulatory problems.

The appeals court agreed with the defense argument that his strokes and heart problems had caused mild dementia, a condition that Chilean law says impedes a defendant from adequately defending himself. ${ }^{215}$

This prediction proved to be correct. The following year, the Supreme Court of Chile affirmed the appellate court decision. ${ }^{216}$ At this writing, it appears that Pinochet has avoided both extradition and prosecution not on grounds of immunity but of incompetence.

\title{
PART II: DECIDING CASES WITH Foreign RELATIONS IMPLICATIONS
}

\section{A. The Abstention Argument.}

Pinochet's request that he be granted habeas corpus on sovereign immunity grounds raised serious questions impinging upon U.K. foreign relations. First, the United Kingdom enjoyed cordial relations with the Pinochet regime. It recognized the junta as Chile's government only eleven

215. Krauss, supra note 214.

216. Pinochet Court Battle Ends, N.Y. TIMES, July 2, 2002, at A11; Pinochet Deemed Unfit for Trial; Ruling Viewed as End of Legal Battle, MIAMI HERALD, July 2, 2002. Subsequent proceedings have ended in the same way. See Larry Rohter, Court Preserves Pinochet's Immunity, N.Y. TIMES, Nov. 9, 2002, at A6 (Supreme Court rejects an Argentine judge's request that Pinochet be questioned); Krauss, supra note 214 (Appeals Court rejects request to permit Pinochet to stand trial for alleged human rights abuses). However, prosecutions of other Pinochet-era officials have proceeded. See Larry Rohter, Chile's Leader Presses Rights Issues Softly but Successfully, N.Y. TIMES, Sept. 7, 2003, at 3 (Chilean judges have proceedings opened on twenty-two generals "accused of abuses during the Pinochet years"); Former Chief of Secret Police Is Indicted by Judge in Chile, N.Y. TIMES, May 16, 2003, at A10 (leader of Pinochet's secret police was indicted "in the 1974 kidnapping of a Spanish priest who was tortured and then disappeared"). Furthermore, as recently as December 2003, efforts to resume Pinochet's prosecution have been discussed. Interview Revives Efforts to Try Pinochet in Chile, WASH. POST, Dec. 4, 2003, at A30 ("Chilean lawyers said [] that they would resume efforts to try former dictator Augusto Pinochet for human rights crimes, asserting that a recent television interview showed he was neither senile nor forgetful."). 
days after it came to power in $1973 .^{217}$ There were widespread reports after Pinochet's arrest that he had been helpful to the United Kingdom in its war against Argentina over the Falkland Islands. ${ }^{218}$ Pinochet was in the United Kingdom with the apparent express consent of the foreign ministry ${ }^{219}$ and enjoyed vocal support from former Prime Minister Margaret Thatcher and other members of the opposition. ${ }^{220}$ The Government itself expressed no view on Pinochet's sovereign immunity claim. ${ }^{221}$

Second, the claim involved a dispute between two U.K. allies. Spain requested Pinochet's extradition under the European Extradition Convention ${ }^{22}$ and its supreme court held that Spanish courts had jurisdiction over crimes of terrorism and genocide committed abroad even if the victims were not Spanish citizens. ${ }^{223}$ For its part, Chile formally intervened in the House of Lords proceedings. ${ }^{24}$ Chile's Senate adopted a formal protest against Spain, charging Spain with violating Chile's sovereignty by asserting extra-territorial jurisdiction and a protest as well against the United Kingdom for disregarding Pinochet's immunity from prosecution as a former head of state. ${ }^{225}$

Third, the claim involved a highly sensitive matter of Chilean domestic politics with serious international relations implications. Chile had returned to democracy through a political compromise that included amnesty for Pinochet. ${ }^{226}$ Similar amnesties were utilized at Zimbabwe's independence in 1980, by South Africa's Truth and Reconciliation Commission, and in El Salvador, Guatemala, and Argentina. ${ }^{227}$ Answering the question of whether such domestic amnesties granted as part of a legitimate national reconciliation effort should be given extra-territorial respect had implications for any nation in transition from a regime arguably guilty of human rights violations.

217. First Law Lords' Judgment, supra note 2, at 919 (Lord Lloyd).

218. See, e.g., Pinochet Faces Extradition Battle, BBC, Nov. 25, 1998, available at http://news.bbc.co.uk/1/hi/uk/221718.stm (last visited Feb. 24, 2004).

219. First Law Lords' Judgment, supra note 2, at 918 (Lord Slynn), 920 (Lord Lloyd).

220. See, e.g., Gibb, supra note 154.

221. Pinochet Arrest Ruled Unlawful, BBC, Oct. 18, 1998, available at http://news.bbc. co.uk/1/hi/uk/203239.stm (last visited Feb. 24, 2004).

222. European Convention on Extradition, supra note 61.

223. First Law Lords' Judgment, supra note 2, at 903 (Lord Slynn).

224. Final Law Lords' Judgment, supra note 4, at 103 (Lord Browne-Wilkinson).

225. First Law Lords' Judgment, supra note 2, at 922 (Lord Lloyd).

226. Id.

227. Ben Chigara, Pinochet and the Administration of Intermational Criminal Justice, in Woodhouse, supra note 95, at 123-25. See also First Law Lords' Judgment, supra note 2, at 929 (Lord Lloyd) ("It has not been argued that these amnesties are as such contrary to international law by reason of the failure to prosecute the individual perpetrators."). There is debate over whether national reconciliation amnesties are breaches of international criminal law. See Chigara, supra. See also First Law Lords' Judgment, supra note 2, at 929. Compare Antonio Cassese, Reflections on International Criminal Justice, 61 MOD. L REV. 1, 3 (1998) (arguing that amnesties will be acceptable under international law in some situations and contradict it in others), with Diana F. Orentlicher, Settling Accounts: The Duty to Prosecute Human Rights Violations of a Prior Regime, 100 YALE L.J. 2537 (1991) (arguing that amnesties are contrary to international law). 
Resolution of Pinochet's request that he be granted habeas corpus on sovereign immunity grounds meant the court had to answer questions such as: Should the United Kingdom deny sovereign immunity to a former head of state with whom the nation had close relations? Should the United Kingdom side with ally Spain or ally Chile? Should the United Kingdom deny extraterritorial effect to Chile's domestic amnesty program?

The values of institutional competence, executive expertise in foreign affairs, democracy, and political branch responsibility for foreign affairs decisions animate the principle of separation of powers in this arena. Because the principle of separation of powers embodies these values, I believe that the U.K. courts should not have decided Pinochet's sovereign immunity claim when presented. The courts should have abstained, dismissing the claim as non-justiciable or, perhaps, not ripe for adjudication. This would have relegated Pinochet to his rights under the Extradition Act, a procedure allowing the executive branch to make the initial determination on such matters as prior acquiescence, the competing claims of Chilean and Spanish allies, and the impact on national reconciliation efforts generally.

As mentioned in the Introduction, my abstention argument is limited. As we have seen, a "provisional warrant" process in which the U.K. government was not involved triggered Pinochet's arrest. Pinochet did not wait for the U.K. government to make a decision on extradition; he immediately took his claim for discharge to the courts. My abstention argument is that the courts should have abstained from making any decision regarding Pinochet that was not before them pursuant to explicit statutorily authorized procedure. Had the court been called upon to decide Pinochet's sovereign immunity claim in a request for habeas corpus following an order of committal or in a request for judicial review following an order of return under the Extradition Act, the separation of powers objections to deciding the claim would largely be eliminated. First, the executive would have had an opportunity to resolve to its satisfaction the foreign relations implications of the extradition request. Second, because the habeas and judicial review procedures are explicitly established by statute, the political legitimacy of the court to rule in this regard is unambiguous.

In the United Kingdom extradition context, Parliament has explicitly provided for judicial review of executive "authority to proceed" and "order for return" decisions. Explicitly conferred with such authority to make a decision with foreign relations implications, I believe the court need not, and perhaps should not, abstain from adjudicating the claim. ${ }^{228}$

228. There are obvious limits to this concept, questions so uniquely political in character (war-making power being a prime example) that courts should not decide them even upon explicit authorization of the political branches. If pressed, I might argue for abstention in a request for habeas corpus following an order of committal, deferring a decision on the merits of the sovereign immunity claim until a request for judicial review following an order of retum. This is because the only review made by the executive prior to an order of committal is the authority to proceed, a cursory inquiry. See supra note 53. 
In many respects, my abstention argument grows from the great constitutional debate over justiciability of the late 1950 s and early 1960 s that took place in the United States. ${ }^{229}$ The crux of the debate was over whether the court itself could employ certain "passive virtues" to decline jurisdiction in certain circumstances ${ }^{230}$ when "jurisdiction under our system is rooted in Article III and congressional enactments."231 I argue for abstention from deciding Pinochet's freestanding habeas corpus claim where I believe (in accordance with the "passive virtues" school) the conflict with the foreign relations powers of the executive branch outweighs any duty to decide the case. But where the legislature has expressly provided for such a claim to be decided in the courts, as Parliament has done in the Extradition Act, I believe the case may and perhaps (in accordance with the "neutral principles" school) must be decided.

In making this argument, I follow six steps. First, I examine the speeches in the Law Lords' Pinochet decisions to see how they handled the foreign relations issues the case raised. Second, I examine the "political question" doctrine for its applicability here. Third, I examine the somewhat different "act of state" doctrine to the same end. Fourth, I review recent developments in the use of both the political question and act of state doctrines that appear to cut against my abstention argument. Fifth, I deal with possible criticisms of my position that the court should nevertheless proceed to adjudicate the claims such as Pinochet's when presented under the explicit procedures of the Extradition Act. I conclude by contending that the abstention argument was viable for the Pinochet situation.

\section{B. Discussing Foreign Relations Issues in Pinochet.}

None of the parties in Pinochet argued that the court should dismiss the case on the basis I propose. Indeed, the judges hearing the habeas claim expressed little reluctance to tackling it. The Lord Chief Justice indicated at one point that for the Home Secretary, rather than the court, to decide Pinochet's claims "could well lead to an unfortunate blurring of functions."232

229. See generally Gerald Gunther, The Subtle Vices of the "Passive Virtues"-A Comment on Principle and Expediency in Judicial Review, 64 CoLUM. L. REV. 1 (1964); AleXANDER M. BICKel, The LEAST Dangerous BranCH (1962); Alexander M. Bickel, The Supreme Court 1960 Term Forward: The Passive Virtues, 75 HARV. L. REV. 40 (1961); Herbert Wechsler, Toward Neutral Principles of Constitutional Law, in PRINCIPLES, POLITICS AND FundaMENTAL LAW (1961); LEARNED HAND, THE BIL OF RIGHTS (1958). I remain grateful to my law school professor, Stanley C. Fickle, for acquainting me with these materials twenty years ago. That they retain viability, see Bush v. Gore, 121 S.Ct. 525, 558 (2000) (Breyer, J., dissenting) (quoting THE LEAST DANGEROUS BRANCH 71).

230. This was the view of HAND and BICKEL, supra note 229.

231. Gunther, supra note 229, at 16. This was also the view of Wechsler, supra note 228.

232. Divisional Court Judgment, supra note 1, at 77-78. The context of the Lord Chief Justice's statement was the following: Under the Extradition Act, a magistrate must notify the Home Secretary upon issuing a provisional warrant. Id. at 74. The Act provides that if the 
The subject of the foreign relations implications of the case was, however, a matter of debate in the speeches in a different way. Pinochet argued that, because of the United Kingdom's record of acquiescence toward Pinochet and because of the domestic political implications in Chile, Pinochet should be granted immunity and allowed to return to Chile. Pinochet also advanced the "act of state" doctrine to the same end. As I shall discuss in greater detail, the act of state doctrine holds that the courts of one sovereign country will not judge the legality of the acts of another country performed within the latter country. Pinochet contended that the act of state doctrine supported his claim to immunity because neither the validity of the warrant nor the propriety of the extradition proceedings could be determined without an investigation by the court of governmental or official acts which largely took place in Chile.

Likely because the Divisional Court recognized Pinochet's statutory claim to sovereign immunity, it did not comment on either of these arguments. The arguments were, however, discussed by the Law Lords in the First Law Lords' Judgment at some length and in the Final Law Lords' Judgment in several places.

In the First Law Lords' Judgment, Lord Slynn found that both the former head of state immunity provision of the State Immunity Act and customary international law supported Pinochet's immunity claim. ${ }^{233}$ Having reached that conclusion, he addressed the foreign relations arguments: "Factors" like the U.K.'s acquiescence to Pinochet's presence, the U.K.'s relations with Chile, and the impact of the decision on domestic politics in Chile "may be relevant on the question whether he should be extradited, but it seems to me that they are for the Secretary of State (the executive branch) and not for your Lordships on this occasion." 234

This point is, of course, entirely consistent with the principle of separation of powers-that these foreign relations considerations are matters for the executive branch, not the courts. The problem with Lord Slynn's

Home Secretary "decides not to issue an authority to proceed in respect of the person to whom the warrant relates," the Home Secretary must cancel the warrant and discharge the person from custody. Id. at 74-75. Pinochet argued that the Home Secretary should have canceled the warrants on both of the grounds alleged, that is, sovereign immunity and the failure to allege an extradition crime. Id. at 76. In Pinochet's view, it should have been "obvious" to the Home Secretary that there was no extradition crime and that he was entitled to immunity as a former sovereign. Id.

The Lord Chief Justice firmly rejected this argument. "It is not the duty of the Home Secretary," he wrote,

to review the legal validity of a provisional warrant. If legal objections to the validity of such a warrant are raised, the Home Secretary is perfectly entitled to take the view that it is for the court and not for him to resolve what may be vexed questions of law. Any other approach could well lead to an unfortunate blurring of functions.

Id. at 77-78.

233. First Law Lords' Judgment, supra note 2, at 918 (Lord Slynn).

234. Id. 
observation, however, is that by voting to grant Pinochet's immunity as he did, he did not leave these foreign relations issues to the executive but effectively decided them himself.

As to Pinochet's act of state argument, Lord Slynn said:

[I]n my opinion once it is established that the former head of state is entitled to immunity from arrest and extradition on the lines I have indicated, United Kingdom courts will not adjudicate on the facts relied on to ground the arrest, but in Lord Wilberforce's words, they will exercise "judicial restraint or abstention."235

Lord Slynn's reference is to Lord Wilberforce's opinion in Buttes Gas \& Oil Co. v. Hammer, ${ }^{236}$ a case I discuss at length below involving two oil companies' dispute over drilling rights in the Persian Gulf. ${ }^{237}$ Suffice it to say here that in Buttes Gas, the court did abstain, dismissing the complaint and counterclaim of both companies as non-justiciable, leaving them to resolve their claims through negotiations. ${ }^{238}$ But Lord Slynn's vote was not to abstain; he voted to decide Pinochet's case on the merits. ${ }^{239}$

Lord Lloyd was also of the view that the statutory former head of state immunity provision of the State Immunity Act and common law both provided Pinochet with the immunity he sought. ${ }^{240}$ After discussing the statutory and common law arguments, Lord Lloyd turned to the issue of "non-justiciability," a question he termed one of "overriding importance." 241 Lord Lloyd reviewed Lord Wilberforce's analysis in Buttes Gas, and his conclusion was that the case raised issues "upon which [the] court could not pass."242 Lord Lloyd then applied Lord Wilberforce's principle of non-justiciability to the Pinochet claim. ${ }^{243} \mathrm{He}$ identified the claims of Spain and other states of the right to try Pinochet; Chile's demand for his return; Chile's general amnesty and the work of its Commission of Truth and Reconciliation; its supreme court's ruling that the amnesty did not apply to some of Pinochet's crimes; and he determined that issues of great sensitivity have arisen between Spain and Chile with the United Kingdom caught in the "cross fire"-if the warrant is quashed, Spain will complain; if not, Chile will complain. ${ }^{244} \mathrm{He}$ concluded:

235. Id. at 919 (quoting Buttes Gas \& Oil Co. v. Hammer, [1982] A.C. 888, 931).

236. Buttes Gas \& Oil Co. v. Hammer, [1982] A.C. 888.

237. See infra Part II.C.

238. Buttes Gas \& Oil Co., [1982] A.C. at 938.

239. First Law Lords' Judgment, supra note 2, at 917 (Lord Slynn).

240. First Law Lords' Judgment, supra note 2 (Lord Lloyd).

241. Id.

242. Id. at 933-35 (Lord Lloyd).

243. See First Law Lords' Judgment, supra note 2 (Lord Lloyd).

244. Id. 
In these circumstances, . . . by assuming jurisdiction, we would only serve to "imperil the amicable relations between governments and vex the peace of nations[.]" [W]e would be entering a field in which we are simply not competent to adjudicate. We apply customary international law as part of the common law, and we give effect to our international obligations so far as they are incorporated in our statute law; but we are not an international court. For an English court to investigate and pronounce on the validity of the amnesty in Chile would be to assert jurisdiction over the internal affairs of that state at the very time when the Supreme Court in Chile is itself performing the same task. In my view this is a case in which, even if there were no valid claim to sovereign immunity, as I think there is, we should exercise judicial restraint by declining jurisdiction. ${ }^{245}$

To me, Lord Lloyd's analysis seems right on target, but his result seems unprincipled and result-driven. Instead of ordering the case dismissed, he concludes, "[i]f I had not been of the view that Senator Pinochet is entitled to immunity as a former head of state, I should have held that the principle of non-justiciability applies." ${ }^{446}$ His justification for this startlingly proposition was that the "whole thrust of Lord Wilberforce's speech was that nonjusticiability is a flexible principle, depending on the circumstances of the particular case."247

Lord Nicholls delivered the third speech in the First Law Lords' Judgment and, as mentioned above, voted to deny Pinochet immunity. ${ }^{248} \mathrm{He}$ addressed the act of state argument early in his speech. ${ }^{249}$ Describing it as a "common law principle of uncertain application," he found it unnecessary to give the issue extended treatment because "there can be no doubt that it yields to a contrary intention shown by Parliament. Where Parliament has shown that a particular issue is to be justiciable in the English courts, there can be no place for the courts to apply this self-denying principle."250

Lord Nicholls said that because Parliament had adopted the International Convention Against Torture and Other Cruel, Inhuman and Degrading Treatment or Punishment, which, by its terms, criminalizes extra-territorial torture committed by officials acting in an official capacity, ${ }^{251}$ Parliament could not have intended for the act of state doctrine to apply in such cases. ${ }^{252}$

245. First Law Lords' Judgment, supra note 2, at 934-35 (Lord Lloyd) (citation omitted).

246. Id. at 935 (Lord Lloyd).

247. Id.

248. See First Law Lords' Judgment, supra note 2 (Lord Nicholls).

249. See id.

250. Id. at 938 (Lord Nicholls).

251. Torture Convention, supra note 8.

252. First Law Lords' Judgment, supra note 2, at 938 (Lord Nicholls). 
Invoking a statute in this way seems to me to be highly justified. While I argue that the court should have abstained and allowed the extradition proceedings to go forward, as a matter of separation of powers, the deference to the legislature Lord Nicholls shows here is entirely defensible. ${ }^{253}$

The last speech in the First Law Lords' Judgment came from Lord Steyn. ${ }^{254} \mathrm{He}$ was also of the view that the acts Pinochet was accused of committing were not the acts of state protected by the former head of state immunity provision of the State Immunity Act; therefore, Pinochet was not entitled to statutory immunity. ${ }^{255} \mathrm{He}$, too, summarily rejected any claim of immunity as a matter of customary international law. ${ }^{256}$

Lord Steyn then turned to the foreign relations arguments. ${ }^{257}$ In language very much like Lord Slynn's, he said that "plainly" it was inappropriate for the court "to take into account such political considerations" as the U.K.'s acquiescence to Pinochet's presence, the U.K.'s relations with Chile, and the impact of the decision on domestic politics in Chile. ${ }^{258}$

Furthermore, he rejected Pinochet's act of state doctrine argument for three reasons. ${ }^{259}$ First, in his view, the court was not being asked to investigate or pass judgment on the facts alleged in the warrant or request for extradition but only to consider and decide the legal issues of immunity and act of state. ${ }^{260}$ Second, to employ the act of state doctrine in the way advanced by Pinochet would override what Lord Steyn characterized as "the intent of Parliament" that statutory immunity not extend to a "former head of state in respect of the systematic torture and killing of his fellow citizens."261 This, Lord Steyn said, would stretch the act of state doctrine "far beyond anything said in the Buttes Gas case . . ."262 Third, he viewed the act of state doctrine as having been "displaced" by Parliament's enactment of the torture prohibitions of the Criminal Justice Act and the provisions of the Hostage Act. ${ }^{263}$

In the Final Law Lords' Judgment, three of the Law Lords referred to the act of state doctrine in their speeches. But each treated it simply as an adjunct of the sovereign immunity doctrine itself. Because each found that sovereign immunity was not available to Pinochet, each found by necessary implication that the act of state doctrine did not apply either. ${ }^{264}$

253. See generally infra Part III.

254. First Law Lords' Judgment, supra note 2 (Lord Steyn).

255. Id.

256. Id. at 946 (Lord Steyn).

257. See id.

258. Id. at 946 (Lord Steyn).

259. First Law Lords' Judgment, supra note 2 (Lord Steyn).

260. Id.

261. Id.

262. Id.

263. Id. at 946-47 (Lord Steyn).

264. Final Law Lords' Judgment, supra note 4, at 170 (Lord Saville), 171-72 (Lord Millett), 186 (Lord Phillips). 


\section{Authority Supporting the Abstention Argument.}

I believe that cases decided in both the United Kingdom and the United States under the "political question" and "act of state" doctrines provide a jurisprudential basis for my claim that the U.K. courts should have dismissed Pinochet's habeas claim in deference to the separation of powers value of institutional competence.

\section{Political Question Cases with Foreign Relations Implications.}

In United States v. Curtiss-Wright Export Corp., ${ }^{265}$ the U.S. Supreme Court recognized "very delicate, plenary and exclusive power" on the part of the President "as the sole organ of the nation in its external relations, and its sole representative with foreign nations." ${ }^{266}$ Because of the allocation of foreign relations authority to the executive, the court has found issues, such as the following, as outside the purview of judicial review: ${ }^{267}$ whether the credentials of foreign diplomat were valid $;{ }^{268}$ whether one ratifying a treaty on behalf of a foreign nation had the power to do so; ${ }^{269}$ whether a new nation should be recognized, ${ }^{270}$ whether a state of war existed; ${ }^{271}$ whether a treaty had been broken; ${ }^{272}$ and whether the President properly refused to grant a foreign air flight license. ${ }^{273}$

These cases each stand for the proposition that the "political question" doctrine precludes judicial scrutiny of controversies involving Presidential and Congressional handling of a foreign affairs matter. On this, one political scientist has written:

Separation of powers mostly limits the Court itself. Broadly speaking, most foreign policy decisions are beyond judicial review. The prime rationale is the fuzzy political question doctrine: that courts cannot consider subjects belonging by law, function, or prudence to political branches. Territorial boundaries, recognition of governments, termination of hostilities, abrogation of treaties, the legality of the Vietnam War, are all controversial instances of this judicial self-

265. United States v. Curtiss-Wright Export Corp., 299 U.S. 304 (1936).

266. Curtiss-Wright Export Corp., 299 U.S. at 319 (quoting Justice Marshall).

267. The citations to the following cases were collected in United States $v$. Martinez, 904 F.2d 601 (11th Cir. 1990).

268. In re Baiz, 135 U.S. 403 (1890).

269. Doe v. Braden, 57 U.S. 635 (1854).

270. United States v. Palmer, 16 U.S. 610 (1818).

271. The Divina Pastora, 17 U.S. 52 (1819).

272. Ware v. Hylton, 3 U.S. 199 (1796).

273. Chicago \& S. Air Lines v. Waterman S.S. Corp., 333 U.S. 103 (1948). 
abrogation. Barriers against excessive delegation of powers by the legislative branch also are minimal. ${ }^{274}$

\section{"Act of State" Doctrine.}

A second doctrine, the "act of state" doctrine, also has been invoked as a restraint on judicial scrutiny in foreign relations cases where the legality of action by a foreign country within its own borders is in question. The earliest case invoking this principle that $I$ have found is the 17th century English case, Blad v. Banfield. ${ }^{275}$ There, a Danish citizen, who had been granted exclusive trading rights in the Danish colony of Iceland by the King of Denmark, seized the property of several Englishmen trading there. Finding this to be "a case of state," the English chancery court refused to question the legality of the exclusive trading rights granted by the King of Denmark over Danish territory.

Often cited is the 1844 House of Lords case, Duke of Brunswick v. King of Hanover. ${ }^{276}$ The case involved an instrument issued pursuant to a decree of the German Diet that deprived the plaintiff of control over the Duchy of Brunswick and appointed his brother in his place. ${ }^{277}$ The plaintiff sought to have the instrument declared invalid in the English courts. ${ }^{278}$ Because the instrument had been issued by, and thus was an act of, a sovereign, the Lord Chancellor, joined by all of the other members of the court, held that the House of Lords could not "inquire into it."279 Although acknowledging that there were certain unique aspects of Duke of Brunswick, Lord Wilberforce would argue in 1982 that "the case [was] nevertheless support . . . [for] a principle of non-justiciability by the English courts of a certain class of sovereign acts." 280

The leading early U.S. act of state case is the 1897 Supreme Court decision Underhill v. Hernandez. ${ }^{281}$ In that case, an American businessman working in Venezuela sought compensation in U.S. courts for damages he and his business suffered when he became embroiled in a revolution there. ${ }^{282}$ Chief Justice Fuller rejected the claim with a formulation of the act of state doctrine used in almost every such case:

Every sovereign State is bound to respect the independence of every other sovereign State, and the courts of one

274. J. Woodford Howard, Jr., Foreign Affairs and Foreign Policy, in THE OXFORD COMPANION TO THE SUPREME COURT OF THE UNITED STATES 307 (Kermit L. Hall ed., 1992).

275. Blad v. Banfield, 3 Swan. 604 (Ch. 1674), 36 Eng. Rep. 992 (1904).

276. Duke of Brunswick v. King of Hanover, 9 Eng. Rep. 993 (1848).

277. Id.

278. Id.

279. Id. at 1000 (Lord Chancellor Cottenham).

280. Buttes Gas \& Oil Co., [1982] A.C. at 932-33 (Lord Wilberforce).

281. Underhill v. Hernandez, 168 U.S. 250 (1897).

282. Id. at 253-54. 
country will not sit in judgment on the acts of the government of another done within its own territory. Redress of grievances by reason of such acts must be obtained through the means open to be availed of by sovereign powers as between themselves. ${ }^{283}$

A series of cases with similar facts in both the United States and the United Kingdom have used similar act of state doctrine language to decline to examine the legality of acts of foreign states. For example, in American Banana Co. v. United Fruit Co. ${ }^{284}$ where Costa Rican soldiers seized an American banana plantation business in Panama in the aftermath of Panama's war of independence from Columbia, the Supreme Court refused to hold the Costa Rican action illegal. In Luther v. James Sager \& Co., ${ }^{285}$ involving competing claims to a quantity of plywood that the defendants had purchased from a Russian factory after it had been nationalized by the Soviet government, the U.K. Court of Appeal refused to find the Soviet action illegal. Two other Russian Revolution cases, Princess Paley Olga $v$. Wiesz ${ }^{286}$ in the United Kingdom and United States $v$. Belmont ${ }^{287}$ in the United States also upheld nationalization action in the Soviet Union.

\section{"Act of State" as a Separation of Powers Doctrine.}

Here I need to make an important point. It is clear that the political question doctrine is a doctrine of justiciability. A court will not adjudicate such questions because to do so would impinge upon the constitutional prerogatives of the political branches of government. But is the act of state doctrine a doctrine of justiciability as well? Consider this language from the Duke of Brunswick case: the claim is that "the instrument was contrary to the laws of Hanover and Brunswick, but, notwithstanding that it is so stated, still if it is a sovereign act, then, whether it be according to law or not according to law, we cannot inquire into it." 288 To the same effect is this language from the American Banana case: To apply the law of the forum jurisdiction rather than that of the place where the acts occurred "not only would be unjust, but would be an interference with the authority of another sovereign, contrary to the comity of nations, which the other state concerned justly might resent."289

283. Id. at 252.

284. See Am. Banana Co. v. United Fruit Co., 213 U.S. 327 (1909).

285. See Luther v. James Sager \& Co., 3 K.B. 532 (C.A. 1921).

286. Princess Paley Olga v. Wiesz, 1 K.B. 718 (C.A. 1929).

287. United States v. Belmont, 301 U.S. 324 (1937).

288. Duke of Brunswick v. King of Hanover, 9 Eng. Rep. 993, 1000 (1848) (Lord Chancellor Cottenham).

289. American Banana, 213 U.S. at 356. 
The implications of these two quotations - and there are many cases that use similar language -is that the act of state doctrine is simply a formulation of the doctrine of sovereign immunity applicable where the acts of a sovereign performed in that sovereign's country are called into question in another jurisdiction. As we have seen, Pinochet attempted to invoke the act of state doctrine in precisely this way in making his sovereign immunity claim: ${ }^{290}$ the State Immunity Act provides former heads of state immunity with respect to "acts performed ... in the exercise of the functions of a head of state"; ${ }^{291}$ under the act of state doctrine, the U.K. courts were required to assume the legality of his actions in Chile; as such, he was entitled to the immunity conferred by the statute.

But the act of state doctrine has a separation of powers pedigree as well. Starting at least with the case of Oetjen v. Central Leather Co. ${ }^{292}$ a 1918 U.S. Supreme Court case, the court used separation of powers rationale, as well as sovereign immunity considerations, in refusing to question the legality of property confiscated by ultimately successful Mexican revolutionaries. Oetjen is one of the most frequently cited act of state cases both in the United States and in the United Kingdom.

Additional support for the act of state doctrine as a separation of powers principle comes from the post-World War II era Bernstein litigation. ${ }^{293}$

290. First Law Lords' Judgment, supra note 2 (Lord Steyn),

291. Id. at 946 (Lord Steyn).

292. Oetjen v. Cent. Leather Co., 246 U.S. 297 (1918).

293. See Bernstein v. N. V. Nederlandsche-Amerikaansche, Stoomvaart-Maatschappij, 210 F.2d 375 (2d Cir. 1954).

The Bernstein litigation involved two cases. In the first, Bernstein v. Van Heyghen Freres Societe Anonyme, 163 F.2d 246 (2d Cir. 1947), Judge Learned Hand held the court strictly limited by the act of state doctrine to recognizing the validity of the Nazi actions alleged. Hand acknowledged that the court would not adhere to the act of state doctrine if "the foreign rights and liabilities [are] abhorrent to the moral notions of its own state." Id. at 249. But it was up to the government, not the court, to determine whether the Nazi behavior at issue was abhorrent to American moral notions. Id. Judge Hand then examined American regulations for occupied post-war Germany and found no provision for settling claims like Bernstein's. Id. Nor did he find any American executive branch assent to hearing claims like Bernstein's in America's prosecution of Nazi war crimes at Nuremberg. Id. Unable to find that the executive branch waived application of the act of state doctrine in this case, Judge Hand ordered Bernstein's claim dismissed. Id.

Soon thereafter, Bernstein's claim with respect to his other steamship line also reached the Second Circuit. Following Van Heyghen, the district court's dismissal was affirmed. Bernstein v. N. V. Nederlandsche-Amerikaansche, 173 F.2nd 71 (2d Cir. 1949). It was following that decision that the State Department issued a press release announcing that it was the administration's policy,

with respect to claims asserted in the United States for restitution of property, is to relieve American courts from any restraint upon the exercise of their jurisdiction to pass upon the validity of the acts of Nazi officials involved in Nazi forced transfers, to free American courts from any restraint upon the exercise of their jurisdiction to pass upon the validity of the acts of Nazi officials.

Bernstein v.N. V. Nederlandsche-Amerikaansche, Stoomvaart-Maatschappij, 210 F.2d 375 (2d Cir. 1954). In the face of this pronouncement, the court amended its mandate to remove any restrictions imposed by the act of state doctrine. Id. 
Bernstein attempted to recover in a U.S. court two steamship companies, which he contended Nazi authorities pressured him to sign over to others with threats of indefinite imprisonment, torture, and death. Under the act of state doctrine, the court would have recognized the validity of the Nazi actions alleged. But the State Department announced that it was the administration's policy that American courts were free from any restraint to pass upon the validity of the acts of Nazi officials. On this basis, the litigation proceeded.

If the act of state doctrine is simply a species of broader sovereign immunity principles, the U.S. State Department could not waive it; after all, it is a foreign state's immunity that is at stake. But if the act of state doctrine is a matter of separation of powers-that courts will not intrude upon the prerogatives of the executive-then in logic there is no reason why the executive should not be free to disclaim any impingement on its prerogatives. ${ }^{294}$ Thus Bernstein appears to establish that the act of state doctrine is grounded in separation of powers, not sovereign immunity considerations.

I think all of this was made clear in an important U.S. Supreme Court case, Banco Nacional de Cuba v. Sabbatino. ${ }^{295}$ Sabbatino was a Cold War case reminiscent of the Latin American and Russian Revolution confiscation cases. At issue were the proceeds of sugar that had been sold after the Castro regime's nationalization of Cuba's sugar industry. There is a great deal in Sabbatino relevant to our discussion and I will return to it in Part III of this article. The present discussion focuses on its analysis of the act of state doctrine.

Justice Harlan rejected broad claims that international law or American constitutional law compels the act of state doctrine. At the same time, he concluded that the rule is binding on federal and state courts. In the end, the act of state doctrine "depends on its capacity to reflect the proper distribution of functions between the judicial and political branches of the Government on matters bearing upon foreign affairs."296 This will in turn depend upon the extent to which the political branches have acted in a particular area of international law, the degree of political sensitivity involved, and whether the government which perpetrated the challenged act of state is no longer in existence (to wit, Bernstein). ${ }^{297}$

But although Justice Harlan's formulation was flexible, he applied it very narrowly.

[R]ather than laying down or reaffirming an inflexible and all-encompassing rule in this case, we decide only that the Judicial Branch will not examine the validity of a taking of

294. I say there is no such impingement as a matter of logic. There could nevertheless be constitutional limitations on such waivers.

295. Banco Nacional de Cuba v. Sabbatino, 376 U.S. 398 (1964).

296. Id. at 427-28.

297. Id. at 428. 
property within its own territory by a foreign sovereign government, extant and recognized by this country at the time of suit, in the absence of a treaty or other unambiguous agreement regarding controlling legal principles, even if the complaint alleges that the taking violates customary international law. ${ }^{298}$

\section{Buttes Gas \& Oil Co. v. Hammer.}

This brings me to Buttes Gas \& Oil Co. v. Hammer, the 1982 decision of the House of Lords mentioned in several of the Pinochet speeches. ${ }^{299}$ The Buttes Gas litigation grew out of a dispute between two American oil exploration companies over drilling rights to an area of the Persian Gulf. One claimed its rights by grant from one of the Arab Emirates; the other by grant from a different Emirate. Crucial to the claim of Buttes Gas was a decree of sovereignty over the disputed area of the Gulf that Occidental claimed had been unlawfully and fraudulently backdated. There were also claims by Iran and the United Kingdom that further complicated the litigation.

Buttes Gas argued that the act of state doctrine dictated that the court not examine the legitimacy of the allegedly backdated decree. Occidental responded that exceptions to the act of state doctrine for principles of international law and extraterritoriality applied here and so the court was permitted to examine the legitimacy of the decree.

Lord Wilberforce delivered the court's judgment. He rejected Occidental's arguments on these two points; however, making a point central to my argument, he said that the act of state doctrine alone was not enough to justify deciding this issue in Buttes Gas's favor: "I do not regard the case against justiciability of the instant disputes as validated by the rule itself. If it is to be made good it must be upon some wider principle." 300 And that wider "principle, if existing," Lord Wilberforce continued, would not be a variation of the act of state doctrine but a principle of "judicial restraint or abstention."301

The question he addresses is this: When a court is faced with disputes involving actions of foreign governments, should it apply the act of state doctrine as a rule of decision so that, once applied, the outcome is dictated? Or is the act of state doctrine really a species of the broader doctrine that courts should not attempt to decide some questions. Lord Wilberforce believes the latter is the case:

298. Id.

299. First Law Lords' Judgment, supra note 2, at 919 (Lord Slynn), 933-34 (Lord Lloyd), 937 (Lord Nicholls), at 946-47 (Lord Steyn).

301. Buttes Gas \& Oil Co., [1982] A.C. at 931. 
In my opinion there is, and for long has been, such a general principle, starting in English law, adopted and generalized in the law of the United States of America which is effective and compelling in English courts. This principle is not one of discretion, but is inherent in the very nature of the judicial process. ${ }^{302}$

He reaches this conclusion by a survey of many of the English and American cases discussed above, including Underhill and Oetgen. He concludes his historical review with the following characterization of Sabbatino:

[I]nternational law does not require application of the doctrine of "act of state." Granted this, and granted also, as the respondents argue, that United States' courts have moved towards a "flexible" use of the doctrine on a case to case basis, there is room for a principle, in suitable cases, of judicial restraint or abstention. ${ }^{303}$

He then turned to a discussion of cases in U.S. courts in which Occidental and Buttes Gas had also litigated the exploration question. Two federal district courts had dismissed the case; both were affirmed on appeal. ${ }^{304}$ While the case was pending in the district court, Lord Wilberforce noted, the U.S. State Department submitted a letter to the court which said in part:

We believe that the political sensitivity of territorial issues, the need for unquestionable U.S. neutrality and the harm to our foreign relations which may otherwise ensue, as well as the evidentiary and jurisprudential difficulties for a U.S. court to determine such issues, are compelling grounds for judicial abstention.

We do not believe that this judicial self-restraint should turn on such analytical questions as whether the so-called Act of State doctrine which is traditionally limited to governmental actions within the territory of the respective state can apply to an exercise of disputed territorial jurisdiction. It rather follows from the general notion that national courts should not assume the function of arbiters of territorial conflicts

304. See Occidental of Umm Al Qaywayn, Inc. v. Cities Serv. Oil Co., 396 F. Supp. 461 (W.D. La. 1975), aff'd sub nom. Occidental of Umm al Qaywayn, Inc. v. A Certain Cargo of Petroleum Laden Aboard Tanker Dauntless Colocotronis, 577 F.2d 1196 (5th Cir. 1978); Occidental Petroleum Corp. v. Buttes Gas and Oil Co., 331 F. Supp. 92 (C.D. Cal. 1971), aff d, 461 F.2d 1261 (9th Cir. 1972), cert. denied, 409 U.S. 950. 
between third powers even in the context of a dispute between private parties. ${ }^{305}$

Lord Wilberforce acknowledged that constitutional notions of separation of powers differentiate the United States and United Kingdom and also that the U.K. government (unlike the U.S. government) had made no request for judicial abstention in the Occidental-Buttes Gas dispute. ${ }^{306}$ "But," he said, "the ultimate question [of] what issues are capable, and what are incapable, of judicial determination must be answered in closely similar terms in whatever country they arise, depending, as they must, upon an appreciation of the nature and limits of the judicial function." 307 Deciding the Occidental-Buttes Gas litigation, Lord Wilberforce found, would require the court to determine "interstate issues" and "issues of international law" beyond the limits of the judicial function. ${ }^{308}$ "Leaving aside all possibility of embarrassment in our foreign relations," he said, "there are ... no judicial or manageable standards by which to judge these issues . . .."309 Because both Buttes Gas's claim and Occidental's counterclaim could not "succeed without bringing to trial non-justiciable issues[,]" the court held that they could not "be entertained."

\section{Summary.}

In summary, the political question doctrine has long stood for the proposition that courts will not adjudicate foreign relations questions within the prerogative of the political branches. And while the act of state doctrine has been employed to decide a species of sovereign immunity claims, there is strong authority from both U.S. and U.K. courts, that it, like the political question doctrine, is also a doctrine of justiciability grounded in the institutional competence value that animates the separation of powers principle.

\section{Authority Raising Questions About the Abstention Argument.}

The authority discussed in the preceding section supports the abstention argument, i.e., that the U.K. courts should have abstained on separation of powers grounds from deciding Pinochet's habeas claim. They identify the institutional competence, if not constitutional preeminence, of the executive in foreign relations matters in holding that the issues presented are not

305. Buttes Gas \& Oil Co., [1982] A.C. at 936 (quoting Occidental of Umm al Qaywayn, 577 F.2d at 1204 n.13).

306. Id.

307. Id.

308. Id.

309. Id.

310. Id. at 938 . 
appropriate for judicial review. But at least since Baker v. Carr, ${ }^{311}$ there is authority that the judiciary can play a role in at least some cases with foreign relations implications.

Baker v. Carr.

Baker v. Carr, of course, was the famous case that opened the door for the Supreme Court's equally famous "one person-one-vote" decision in Reynolds v. Sims. ${ }^{312}$ At issue in Baker v. Carr was whether, under the political question doctrine, the court had the power to review state legislative apportionment schemes. In the course of concluding that some political questions were justiciable, Justice Brennan analyzed the limits of court authority in "representative" political question cases. ${ }^{313}$ Among the cases he reviewed were those with foreign relations implications. Citing Oetjen, he began by saying that "[ $t$ ]here are sweeping statements to the effect that all questions touching foreign relations are political questions." ${ }^{\text {"14 }}$ He acknowledged that "resolution of such issues frequently turn on standards that defy judicial application, or involved the exercise of a discretion demonstrably committed to the executive or legislature."315 Further, "many such questions uniquely demand singlevoiced statement of the Government's views." But it would be a mistake, Justice Brennan argued, "to suppose that every case or controversy which touches foreign relations lies beyond judicial cognizance." 316

A court might well take on a foreign relations question depending upon "the history of its management by the political branches, of its susceptibility to judicial handling in the light of its nature and posture in the specific case, and of the possible consequences of judicial action," 317 Justice Brennan wrote. He presented several examples he felt supported this proposition. ${ }^{318}$ In any

311. Baker v. Carr, 369 U.S. 186 (1962).

312. Reynolds v. Sims, 377 U.S. 533 (1964).

313. Baker, 369 U.S. at 211.

314. Id.

315. Id.

316. Id.

317. Id. at 211-12.

318. Here is Justice Brennan's analysis:

For example, though a court will not ordinarily inquire whether a treaty has been terminated, since on that question "governmental action ... must be regarded as of controlling importance," if there has been no conclusive "governmental action" then a court can construe a treaty and may find it provides the answer. Compare Terlinden v. Ames, 184 U.S. 270, 285, with Society for the Propagation of the Gospel in Foreign Parts v. New Haven, 8 Wheat. 464, 492-495. Though a court will not undertake to construe a treaty in a manner inconsistent with a subsequent federal statute, no similar hesitancy obtains if the asserted clash is with state law. Compare Whitney v. Robertson, 124 U.S. 190, with Kolovrat v. Oregon, 366 U.S. 187.

While recognition of foreign governments so strongly defies judicial treatment that without executive recognition a foreign state has been called "a 
event, he uses the examples of court decision-making in the foreign relations area, together with examples drawn from other political question cases, to pronounce the now-familiar test for justiciability of political questions:

Prominent on the surface of any case held to involve a political question is found a textually demonstrable constitutional commitment of the issue to a coordinate political department; or a lack of judicially discoverable and manageable standards for resolving it; or the impossibility of deciding without an initial policy determination of a kind clearly for nonjudicial discretion; or the impossibility of a court's undertaking independent resolution without expressing lack of the respect due coordinate branches of government; or an unusual need for unquestioning adherence to a political decision already made; or the potentiality of embarrassment from multifarious pronouncements by various departments on one question.

Unless one of these formulations is inextricable from the case at bar, there should be no dismissal for non-justiciability on the ground of a political question's presence. ${ }^{319}$

After Baker v. Carr, courts in the United States had a much wider array of tools with which to address cases implicating foreign relations. While the political question doctrine still recognized the allocation of foreign relations responsibilities to the executive and legislative branches, it was now formulated in a way that allowed courts to decide political questions. Finding a political question touching on foreign relations non-justiciable had become a much more complicated exercise.

republic of whose existence we know nothing," and the judiciary ordinarily follows the executive as to which nation has sovereignty over disputed territory, once sovereignty over an area is politically determined and declared, courts may examine the resulting status and decide independently whether a statute applies to that area. Similarly, recognition of belligerency abroad is an executive responsibility, but if the executive proclamations fall short of an explicit answer, a court may construe them seeking, for example, to determine whether the situation is such that statutes designed to assure American neutrality have become operative. The Three Friends, 166 U.S. 1, 63, 66. Still again, though it is the executive that determines a person's status as representative of a foreign government, Ex parte Hitz, 111 U.S. 766, the executive's statements will be construed where necessary to determine the court's jurisdiction, In re Baiz, 135 U.S. 403. Similar judicial action in the absence of a recognizably authoritative executive declaration occurs in cases involving the immunity from seizure of vessels owned by friendly foreign governments. Compare Ex parte Peru, 318 U.S. 578, with Mexico v. Hoffman, 324 U.S. 30, 34-35.

Baker, 369 U.S. at 212-13 (footnotes omitted).

319. Id. 
Goldwater v. Carter.

The difficulty created by Baker $v$. Carr of deciding which foreign relations cases are justiciable and which are not was well illustrated by Goldwater v. Carter. ${ }^{320}$ As part of the President's decision to recognize the Chinese government in Beijing, the President terminated the U.S. treaty with the government of Taiwan. Senator Goldwater and certain other members of Congress claimed that the President's action in terminating the treaty with Taiwan deprived them of their constitutional role with respect to treaties. Six members of the court voted to dismiss Senator Goldwater's complaint, but there was no definitive answer to whether the case presented a non-justiciable political question. ${ }^{321}$ Although that was the position taken in an opinion written by Justice Rehnquist, his viewpoint mustered only four votes. ${ }^{322}$

Justice Rehnquist contended that the case presented a non-justiciable political question for two reasons. First, the case involved "the extent to which the Senate or the Congress is authorized to negate the action of the President." 323 He argued that because there was no "constitutional provision governing the termination of a treaty, and the fact that different termination procedures may be appropriate for different treaties," 324 the case "must surely be controlled by political standards" ${ }^{325}$ rather than court judgment. ${ }^{326}$ Second, the foreign relations aspects of the case made the reason for holding it a non-

320. See Goldwater v. Carter, 444 U.S. 996 (1979).

321. Goldwater, 444 U.S. at 996 . These six justices voted to grant certiorari, vacate the judgment of the Court of Appeals, and remand the case to the district court with instructions to dismiss the complaint. A discussion of their reasoning follows in the text. In addition, Justices White and Blackmun joined the grant of certiorari but would have set the case for argument and given it plenary consideration. Justice Brennan also joined the grant of certiorari but would have affirmed the judgment of the Court of Appeals. A discussion of his reasoning follows in the text.

322. Id. Justice Powell voted to dismiss on grounds that the complaint was not ripe for judicial review. Id. Justice Powell's argument was that

a dispute between Congress and the President is not ready for judicial review unless and until each branch has taken action asserting its constitutional authority. Differences between the President and the Congress are commonplace under our system. The differences should, and almost invariably do, turn on political rather than legal considerations. The Judicial Branch should not decide issues affecting the allocation of power between the President and Congress until the political branches reach a constitutional impasse. Otherwise, we would encourage small groups or even individual Members of Congress to seek judicial resolution of issues before the normal political process has the opportunity to resolve the conflict.

Id. at 997 (Powell, J. concurring). Justice Marshall voted to concur in the result without further explanation. Id. at 996.

323. Goldwater, 444 U.S. at 1002.

324. Id. at 1003.

325. Id.

326. Id. (quoting Dyer v. Blair, 390 F. Supp. 1291,1302 (N.D. Ill. 1975)). 
justiciable political question "even more compelling." 327 Because the Taiwan treaty included a commitment to use military force in the defense of a foreign government if attacked, Justice Rehnquist maintained, its termination affected "a situation entirely external to the United States, and falling within the category of foreign affairs." 328

To Justice Brennan, Justice Rehnquist's analysis "profoundly misapprehend[ed] the political-question principle as it applies to matters of foreign relations." 329 To Justice Brennan, Baker v. Carr held that "the political-question doctrine restrains courts from reviewing an exercise of foreign policy judgment by the coordinate political branch to which authority to make that judgment has been 'constitutional[ly] commit[ted]." "330 The court was not being asked to review a foreign policy judgment here, he said, but rather an "antecedent question whether a particular branch has been constitutionally designated as the repository of political decisionmaking power. The issue of decisionmaking authority must be resolved as a matter of constitutional law, not political discretion; accordingly, it falls within the competence of the courts." 331

Tel-Oren v. Libyan Arab Republic.

The malleability of the political question doctrine was particularly well illustrated ${ }^{332}$ by the 1984 case of Tel-Oren v. Libyan Arab Republic. ${ }^{333}$ A group of survivors and representatives of persons murdered in an armed attack in 1978 on a civilian bus in Israel sued Libya, the PLO, the Palestine

327. Goldwater, 444 U.S. at 1003.

328. Id. at 1003-04 (quoting United States v. Curtiss-Wright Corp., 299 U.S. 304 (1936)).

329. Id. at 1006 .

330. Id. (quoting Baker, 369 U.S. at 211-213, 217).

331. Id. at 1007 (citation omitted).

332. To the same effect, compare United States v. Martinez, 904 F.2d 601, 602 (11 th Cir. 1990) (where a criminal defendant sought a determination that an electronic device which he had been convicted of exporting was not a "defense article" under the Arms Export Control Act, held the request involved "Presidential and Congressional handling of foreign affairs matter" such that the political question doctrine precluded judicial review), and Aktepe v. United States, 105 F.3d 1400 (11 th Cir. 1997) (where Turkish Navy sailors sought damages for personal injury and death when two missiles fired from a U.S. Navy aircraft carrier accidentally struck their vessel during NATO training exercises, dismissed the claims as presenting a non-justiciable political question), with Lamont v. Woods, 948 F.2d 825, 832 (2d Cir. 1991) (where plaintiffs contended that grants under a U.S. foreign aid program that were used to support Israeli schools and schools affiliated with Roman Catholic religious orders violated the Establishment Clause, held that that adjudication of the plaintiffs' claim did not amount to "judicial usurpation of the political branches' constitutional powers to formulate foreign policy"), and Ramirez de Arellano v. Weinberger, 745 F.2d 1500 (D.C. Cir. 1984) (en banc) (where a U.S. citizen sought damages suffered from U.S. military operation of a large military training facility for Salvadoran soldiers on his private ranch in Honduras without his permission or any lawful authority, held, over the dissents of Judges Bork, Scalia, and Starr, that the political question doctrine was not implicated).

333. See Tel-Oren v. Libyan Arab Republic, 726 F.2d 774 (D.C. Cir. 1984) (per curiam). 
Information Office, the National Association of Arab Americans, and the Palestine Congress of North America. Their complaint, alleging multiple torts in violation of international law, U.S. treaties, U.S. criminal law, and common law had been dismissed by the District Court for lack of subject matter jurisdiction and as barred by the applicable statute of limitations. Each of the three judges on the panel also voted to dismiss ${ }^{334}$ but for very different reasons. Two of the judges-Judge Harry Edwards and Judge Robert Bork-engaged in a lengthy debate over whether the Alien Tort Statute, ${ }^{335}$ provided a cause of action for the plaintiffs or was merely jurisdictional. ${ }^{336}$ All three of the judges also examined the underlying justiciability of the claim as a matter of separation of powers in general and political question doctrine in particular. For purposes of our discussion here, the views of the judges on justiciability are relevant; however, I will return later to the Alien Tort Statute debate at several points.

Judge Edwards, following the view of Justice Brennan in Goldwater v. Carter, found no political question impediment to addressing the merits of the claim. ${ }^{337}$ As noted above, Justice Brennan described the political question doctrine in the foreign relations context as "restrain[ing] courts from reviewing an exercise of foreign policy judgment by the coordinate political branch to which authority to make that judgment has been constitutional[ly] commit[ted]." Finding no "exercise of foreign policy judgment" by the executive branch subject to review in this case, Judge Edwards found no justiciability bar to review. ${ }^{339}$

To Judge Bork, this litigation was resolvable on the statutory issue alluded to above. But, he said, "if it were necessary," he "might well hold that the political question doctrine bars this lawsuit, since it is arguable ... that this case fits several of the categories listed in Baker v. Carr." ${ }^{340}$ To that end, he argued that the political question doctrine and the act of state doctrine are the principal doctrinal limitations on judicial power in the international law area required by the separation of powers principle that the conduct of foreign relations is committed to the political branches. Judge Bork worked through

334. Id. at 775 .

335. 28 U.S.C. $\$ 1350$.

336. At issue was the proper interpretation of the Alien Tort Statute. Judge Edwards argued for following Filartiga v. Pena-Irala, 630 F.2d 876 (2d Cir. 1980), discussed infra Part III.D-Customary International Law in the United States; Judge Bork argued to the contrary.

A highly visible attempt to invoke the Alien Tort Statute is provided by Al Odah $v$. United States, 321 F.3d 1134, 1144 (D.C. Cir. 2003), cert. granted, 124 S.Ct. 534. In addition to seeking relief explicitly in the nature of a habeas corpus, detainees held by the U.S. government at Guantanamo Bay have sought injunctions and declaratory judgments under the statute, alleging that the United States is confining them in violation of treaties and international law. See note 17 supra.

337. Tel-Oren, 726 F.2d at 776.

338. Goldwater v. Carter, 444 U.S. 996, 1006 (1979).

339. Tel-Oren, 726 F.2d at 798.

340. Id. at 803. 
the act of state cases, highlighting the growing emphasis on separation of powers considerations. Quoting Sabbatino, he said that " $[\mathrm{t}] \mathrm{he}$ Court emphasized the separation of powers basis for the doctrine when it observed that the doctrine's 'continuing vitality depends on its capacity to reflect the proper distribution of functions between the judicial and political branches of the Government on matters bearing upon foreign affairs." 341 He also pointed out that the "courts of appeals have likewise emphasized the decisive role played, in applying the doctrine, by the two relevant aspects of separation of powers: the potential for interference with the political branches' functions and the fitness of an issue for judicial resolution."342

Judge Bork then argued that the "same separation of powers principles are reflected in the political question doctrine." ${ }^{343}$ Giving a quite different read to Baker v. Carr than Judge Edwards, Judge Bork cited it for the proposition that "[q]uestions touching on the foreign relations of the United States make up what is likely the largest class of questions to which the political question doctrine has been applied." 344

To Judge Robb, the case clearly presented a non-justiciable political question, he found an "inherent inability of federal courts to deal with cases such as this one." ${ }^{345}$ His analysis rested on five principal points. First, he argued that federal courts are not in a position to determine the international status of terrorist acts, given that there are frequently diplomatic efforts "to dignify the violence of terrorist atrocities . . ."346 And given the complex "web" of international terrorism, it would be even more problematic for a court to assess "individual responsibility for any given terrorist outrage.",347

Second, Judge Robb argued that this case involved "questions that touch on sensitive matters of diplomacy that uniquely demand a singlevoiced statement of policy by the Government." 348 Of particular concern to Judge Robb was the necessity, if this case were found to be justiciable, of taking a position on the international status of the PLO, which had not at the time of this case been recognized by the U.S. government. "The courts must be careful to preserve [the President's] flexibility" ${ }^{349}$ to deal or not deal with terrorists. On the other hand, taking on such cases might well publicize and even "legitimize

341. Id. at 802 (per Bork, J.) (quoting Sabbatino, 376 U.S. at 427-28.)

342. Tel-Oren, 726 F.2d at 802-03 (per Bork, J.) (citing Int'l Assoc. of Machinists \& Aerospace Workers v. OPEC, 649 F.2d 1354, 1358-61 (9th Cir. 1981), cert. denied 451 U.S. 1163 (1982); Mannington Mills, Inc. v. Congoleum Corp., 595 F.2d 1287, 1292-93 (3d Cir. 1979); Hunt v. Mobil Oil Corp., 550 F.2d 68, $77-79$ (2d Cir.), cert. denied 434 U.S. 984 (1977); Timberlane Lumber Co. v. Bank of Am., 549 F.2d 597, 605-08 (9th Cir. 1976)).

343. Tel-Oren, 726 F.2d at 803.

344. Id.

345. Id. at 823.

346. Id.

347. Id.

348. Id. at 824.

349. Id. at 825 . 
that which ought to remain hidden and those who deserve the brand of absolute illegitimacy." 350

Judge Robb also argued that questions connected to the activities of terrorists have historically been within the exclusive domain of the executive and legislative branches and that the pragmatic problems associated with proceedings designed to bring terrorists to the bar are numerous and intractable. Finally, he argued that the possible consequences of judicial action in this area were injurious to the national interest. Although this particular case was easy in its contrast between good and evil, "not all cases of this type will be so easy .... Each supposed scenario carries with it an incredibly complex calculus of actors, circumstances, and geopolitical considerations. The courts must steer resolutely away from involvement in this manner of case." 351

\section{Act of State Cases.}

The political question cases just discussed illustrate that, at least since Baker v. Carr, judges and courts have been able to advance arguments to reach the merits of claims with foreign relations implications. This has also been the case with act of state doctrine cases. To illustrate, I have selected a U.K. tax case, Oppenheimer v. Cattermole ${ }^{352}$ and a U.S. case, W.S. Kirkpatrick \& Co. v. Environmental Tectonics Corp. ${ }^{353}$

Oppenheimer, a Jewish refugee from Nazi Germany, was naturalized a British citizen in 1948. After the war, he began to receive a German pension. If - but only if - he was a dual national, continuing to hold German as well as British citizenship, he would be able to take advantage of agreements between Britain and Germany limiting double taxation.

At the outset of the litigation, it appeared that the answer would turn on whether Britain recognized the validity of a 1941 Nazi statute revoking the citizenship of any Jew who fled Germany. The act of state doctrine appeared to require that the courts recognize the validity of the statute but, in addition to the moral consequences of such a conclusion, it would deprive Oppenheimer of the benefit of the agreements against double taxation. However, as the litigation progressed, the parties realized that the German Constitutional Court in 1968 had declared the 1941 Nazi statute to be void $a b$ initio $^{354}$ and so as a matter of German law, Oppenheimer's tax status did not turn on the validity of the 1941 enactment.

The House of Lords decided Oppenheimer, each of the five judges delivered speeches and each agreed that Oppenheimer's tax status did not turn on the validity of the 1941 enactment. But perhaps because the opinions in the

351. Id. at 825-27.

352. See Oppenheimer v. Cattermole, [1976] A.C. 249.

353. See W.S. Kirkpatrick \& Co. v. Envtl. Tectonics Corp., 493 U.S. 400 (1990).

354. Oppenheimer, [1976] A.C. at 267-68 (Lord Cross). 
lower courts had addressed the issue, four of the Law Lords expressed opinions on the issue. The lead speech of Lord Cross, with which Lords Hodson and Salmon agreed, held that it was "part of the public policy of this country that our court should give effect to clearly established rules of international law." 355 Lord Cross acknowledged that it was often difficult to identify an applicable rule of international law and that in any event a judge should be reluctant not to give effect to the law of a foreign state in a matter over which it has jurisdiction.

But, what we are concerned with here is legislation which takes away without compensation from a section of the citizen body singled out on racial grounds all their property on which the state passing the legislation can lay its hands and, in addition, deprives them of their citizenship. To my mind a law of this sort constitutes so grave an infringement of human rights that the courts of this country ought to refuse to recognise it as a law at all. ${ }^{356}$

Lord Pearson took a point of view closer to Judge Hand's in the first Bernstein case. ${ }^{357}$ He would have recognized the validity of the 1941 act, employing the following analysis:

When a government, however wicked, has been holding and exercising full and exclusive sovereign power in a foreign country for a number of years, and has been recognised throughout by our government as the government of that country, and some legislative or executive act of that government, however unjust and discriminatory and unfair, has changed the status of an individual by depriving him of his nationality of that country, he does in my opinion effectively cease to be a national of that country and becomes a stateless person unless and until he has acquired some other nationality (as the appellant Oppenheimer did in this case). Suppose then that the wicked government is overthrown. I do not think it would be right for the courts of this country on their own initiative to disregard that person's change of status which in fact had occurred and deem that it never had occurred. A decision on that fictitious basis might be no kindness to the person concerned, who might be quite content with his new status and unwilling to have his former status artificially

355. Oppenheimer, [1976] A.C. at 278 (Lord Cross).

356. Id.

357. See Bernstein v. Van Heyghen Freres Societe Anonyme, 163 F.2d 246 (2d Cir. 1947), discussed supra note 293. 
restored to him. The problem of effecting any necessary rectification of the position created by the unjust decree of the wicked government is a problem for the successor government of the foreign country, and we know that in the present case the problem was dealt with by the successor government of West Germany by its Basic Law of 1949. But if the successor government had not dealt with the problem, I do not see that the courts of this country would have had any jurisdiction to restore to the person concerned his lost nationality of the foreign country. ${ }^{358}$

Indeed, even Lord Cross had acknowledged certain practical problems with his approach. He noted that many persons affected by the 1941 decree would likely not have wished to remain German nationals and that other countries, despite loathing the 1941 act, had given it effect for that reason. ${ }^{359}$

Of course, given the fact that German law at the time the Law Lords confronted Oppenheimer's case did not require any opinion on the validity of the 1941 Nazi statute, the court need not have rendered any opinion at all. This was the view taken by the final member of the committee, Lord Hailsham. In arguing that the court should express no opinion, he cited authority to the effect that "only in a relatively small proportion of cases is the possession of dual nationality an advantage .... There would seem small value in adding hardship to injustice in order to emphasize the cruel nature of the injustice." And he pointed out that U.K. law might well "not give a single and unequivocal answer to the problems raised by the unjust and discriminatory legislation of a foreign country."

In W.S. Kirkpatrick \& Co. v. Environmental Tectonics Corp., an unsuccessful bidder for a construction contract with the Nigerian government sought damages from the successful bidder under various U.S. statutes, alleging that the successful bidder had obtained the contract by bribing Nigerian officials. ${ }^{361}$ The defendant sought dismissal of the complaint, contending that the "act of state" doctrine precluded judicial inquiry into the motivation of a sovereign act that would result in embarrassment to the sovereign, or constitute interference with the conduct of U.S. foreign policy. ${ }^{362}$

The U.S. Supreme Court rejected the argument, finding that the act of state doctrine did not apply because nothing in the complaint required a court

358. Oppenheimer, [1976] A.C. at 265-66 (Lord Pearson).

359. Id. at 278 (Lord Cross) (citing Dr. F.A. Mann, The Present Validity of Nazi Nationality Laws, 89 L.Q.R. 194 (1973)).

360. Oppenheimer, [1976] A.C. at 263 (Lord Hailsham).

361. The defendant had been found guilty under the Foreign Corrupt Practices Act of 1977 , 91 Stat. 1495, as amended, 15 U.S.C. $\$ 78 \mathrm{dd}-1$.

362. W.S. Kirkpatrick \& Co. v. Entl. Tectonics Corp., 493 U.S. 400, 402 (1990). 
to declare invalid the official act of a foreign sovereign. ${ }^{363}$ But the defendant in Kirkpatrick tried to invoke the "act of state" doctrine as a doctrine of abstention in much the same way as I argue for abstention in Pinochet. It contended that the policies underlying our act of state cases- "international comity, respect for the sovereignty of foreign nations on their own territory, and the avoidance of embarrassment to the Executive Branch in its conduct of foreign relations" 364 - were implicated by the case such that the court should abstain from deciding it.

Justice Scalia, speaking for a unanimous court, resoundingly rejected this argument:

It is one thing to suggest, as we have, that the policies underlying the act of state doctrine should be considered in deciding whether, despite the doctrine's technical availability, it should nonetheless not be invoked; it is something quite different to suggest that those underlying policies are a doctrine unto themselves, justifying expansion of the act of state doctrine (or, as the United States puts it, unspecified "related principles of abstention") into new and uncharted fields.

The short of the matter is this: Courts in the United States have the power, and ordinarily the obligation, to decide cases and controversies properly presented to them. The act of state doctrine does not establish an exception for cases and controversies that may embarrass foreign governments, but merely requires that, in the process of deciding, the acts of foreign sovereigns taken within their own jurisdictions shall be deemed valid. That doctrine has no application to the present case because the validity of no foreign sovereign act is at issue. ${ }^{365}$

\section{Summary.}

My abstention argument holds that U.K. courts should have abstained from deciding Pinochet's habeas claim when presented in deference to the executive's prerogative in the field of foreign relations. This argument is supported by the general principles of the political question and act of state doctrine. But the opinions of Justice Brennan in Baker v. Carr and Goldwater v. Carter, of Judge Edwards in Tel-Oren, and of Lord Cross in Oppenheimer seem to provide license to courts to reach the merits of such claims. And Kirkpatrick suggests that except in the narrowest of circumstances it must. 
On the other hand, the reasoning of Justice Rehnquist in Goldwater $v$. Carter, of Judges Bork and Robb in Tel-Oren, and of Lord Hailsham in Oppenheimer suggest that the abstention argument retains viability even in the post-Baker v. Carr era-that the separation of powers values of institutional competence and democracy dictate that courts defer to the political branches in matters of foreign relations. And two aspects of the Kirkpatrick case make it less troubling to me than Justice Scalia's strong language rejecting abstention might suggest. First, although Justice Scalia said that it was not important to his analysis, the State Department had indicated to the trial court that it had no objection to the court deciding the claim. Second, the claims at issue followed a finding of guilt on the part of the defendant under the Foreign Corrupt Practices Act. ${ }^{366}$ As such, I infer political acquiescence to the adjudication of such claims.

\section{E. Limitation on the Abstention Argument: The Court Need Not Abstain} From Judicial Review Authorized By the Extradition Act.

As previously discussed, my abstention argument is limited. As we have seen, a "provisional warrant" process in which the U.K. government was not involved triggered Pinochet's arrest. ${ }^{367}$ Pinochet did not wait for the U.K. government to make a decision on extradition; he immediately took his claim for discharge to the courts. My abstention argument is that the courts should have abstained from making any decision in Pinochet that was not before them pursuant to explicit statutorily authorized procedure. But had the court been called upon to decide Pinochet's sovereign immunity claim in a request for habeas corpus following an order of committal or in a request for judicial review following an order of return under the Extradition Act, I believe the court could have and perhaps should have decided the claim.

This limitation is susceptible to criticism. It is certainly true that some of the authority I have discussed supports a much stronger version of abstention; a version where even a claim following authority to proceed or order to return would be dismissed as non-justiciable. ${ }^{368}$ It is also true that a court ruling on a claim of former head of state sovereign immunity following authority to proceed or order to return could have exactly the same foreign relations repercussions as those that could follow a claim brought in advance of action under the Extradition Act. But I think it is an important limitation for two reasons.

First, the separation of powers calculus in which we have been operating changes when the political branches acquiesce to or invite judicial participation. When facing a claim brought pursuant to the procedures of the Extradition Act, the separation of powers objections to deciding the claim 
would largely be eliminated. First, the executive would have had an opportunity to resolve to its satisfaction the foreign relations implications of the extradition request. Second, because the habeas and judicial review procedures are explicitly established by statute, the political legitimacy of the court to rule in this regard is unambiguous.

The Bernstein litigation, ${ }^{369}$ the Tel-Oren case, ${ }^{370}$ and even the Kirkpatrick case $^{371}$ discussed earlier suggest analogies to my abstention argument and the limitation I have placed on it. In the Bernstein litigation, the court first applied the act of state doctrine and refused to entertain Bernstein's claim challenging the validity of the Nazi actions alleged. But when the State Department announced that it was the administration's policy that American courts were free from any restraint to pass upon the validity of the acts of Nazi officials, the litigation proceeded. With the acquiescence by the executive branch in such circumstances, a court need not abstain from deciding cases with foreign relations implications.

In Tel-Oren, both Judge Bork and Judge Robb invoked separation of powers concerns in general and political question concerns in particular in arguing that the court should not address the merits of the plaintiffs claims for injuries suffered during a terrorist incident in Israel ${ }^{372}$ Following publication of their opinions, Congress amended the Alien Tort Statute to provide an explicit cause of action in certain circumstances. ${ }^{373}$ With authority to adjudicate such claims provided by the legislative branch in such circumstances, a court need not abstain from deciding cases with foreign relations implications.

In Kirkpatrick, as I have noted, ${ }^{374}$ the court firmly rejected abstaining on act of state grounds. But the case featured a letter from the State Department acquiescing to adjudication and the litigation itself was an offshoot of a criminal prosecution for foreign corrupt practices. With such acquiescence and legislative authority, a court need not abstain from adjudicating claims with foreign policy implications.

Second, broader principles of judicial restraint are also at stake here. I have already mentioned the echoes of the great U.S. constitutional debate over justiciability of the late 1950s and early 1960s where Learned Hand, Herbert Wechsler, Alexander Bickel, and Gerald Gunther contended over whether the

369. See supra Part II.C \& note 293.

370. See supra Part II.D.

371. W.S. Kirkpatrick \& Co. v. Envtl. Tectonics Corp., 493 U.S. 400 (1990).

372. Tel-Oren v. Libyan Arab Republic, 726 F.2d 774, 803 (per Judge Bork), 823 (per Judge Robb) (D.C. Cir. 1984).

373. Largely as a result of Judge Bork's opinion in the Tel-Oren case, taking the position that the Alien Tort Statute did not provide a cause of action, the U.S. Congress in 1991 passed the Torture Victims Protection Act, Pub. L. No. 102-256, 106 Stat. 73 (1992), intended to provide a cause of action where torture is alleged. Gregory H. Fox, International Litigation In Practice: Alien Tort and Other Claims Before National Courts, 94 AM. SOC'Y INT'L L. PROC. 149 (2000).

374. See supra Part I-D-Summary. 
court itself could employ certain "passive virtues" to decline jurisdiction in certain circumstances" ${ }^{375}$ when "jurisdiction under our system is rooted in Article III and congressional enactments." 376 Justice Brandeis's declaration that " $[\mathrm{t}]$ he most important thing we do is not doing" ${ }^{377}$ is the foundation on which Professor Bickel's "passive virtues" are built. ${ }^{378}$ But those virtuesdevices for withholding the ultimate constitutional judgment of the court-do not in my view (or Bickel's or Brandeis's) divest the court of authority ever to act; they only make it possible for the court to postpone acting until a more propitious time. Indeed, it was the argument of Wechsler and Gunther that the Constitution and Congress sets the court's jurisdiction, that it has no business creating jurisdiction on its own. ${ }^{379}$

Much more could be written on this point. I close my argument simply by observing how much better off the U.K. judiciary would have been had the Law Lords abstained. In the course of deciding Pinochet's sovereign immunity claim, the U.K. judiciary embarrassed itself to an enormous degree by having to vacate its first decision because of the improper participation of Lord Hoffmann. ${ }^{380}$ Indeed, the Lord Chancellor, in his capacity as head of the judiciary, was compelled to declare, "We must make every effort to ensure that such a state of affairs could not occur again." 381 Beyond the institutional embarrassment caused by Hoffmann was the less obvious embarrassment of the same court taking up the same issue twice and coming to two conclusions that were the same in result only, ${ }^{382}$ demonstrating what one observer called the "sheer chanciness of appellate decision making . . . more brutally than in any case easily recalled this century." 383 Had the court abstained, none of this embarrassment would have resulted because Straw's decision returning Pinochet to Chile occurred before any judicial review under the Extradition Act reached the House of Lords.

\section{F. Conclusion.}

I believe that it would have been highly consistent with the political question and act of state doctrines-and the separation of powers considerations that they embody-for the U.K. courts to dismiss Pinochet's request for a writ of habeas corpus as non-justiciable when presented. I said

375. This was the view of Hand and Bickel, supra note 229.

376. Gunther, supra note 229, at 16. This was also the view of Wechsler, supra note 229.

377. BICKEL, supra note 229, at 112 (quoting Ashwander v. Tennessee Valley Auth., 297 U.S. 288, 346 (1936) (Brandeis, J., concurring)). This was the passage of The Least Dangerous Branch Justice Breyer referred to in Bush v. Gore, 121 S.Ct. at 558 (Breyer, J., dissenting). See supra note 229.

378. BICKEL, supra note 229 , at 112.

379. See Gunther, supra note 229; Wechsler, supra note 228.

380. See Innocence, supra note 10; Robertson, in Woodhouse, supra note 95, at 25.

381. Press Notice, supra note 16.

382. Robertson, in Woodhouse, supra note 95, at 24.

383. Id. at 17 . 
at the outset that my purpose here was not to suggest that U.S. separation of powers law be adopted as U.K. law. Rather, my abstention argument is that in both countries institutional competence and democracy-values that animate the principle of separation of powers-require the executive branch to exercise the nation's foreign relations power. Not only does the executive possess the necessary expertise to do so but also, as a more theoretical matter, the courts do not enjoy the same legitimacy as do the political branches in decisions that can carry national security implications.

The cases I have mentioned highlight these considerations in litigation involving foreign relations. Sabbatino, for example, noted that inquiries into the validity of foreign acts of state might "seriously interfere with negotiations being carried on by the Executive Branch"384 and, at another point, that such inquiries "would involve the possibility of conflict with the Executive view." ${ }^{385}$ Baker v. Carr, for all the flexibility it introduced into political question analysis, acknowledged that "resolution of [foreign relations] issues frequently turn on standards that defy judicial application, or involve the exercise of a discretion demonstrably committed to the executive or legislature. . .."386 Further, "many such questions uniquely demand single-voiced statement of the Government's views." 387 And remember Lord Wilberforce's dismissal of both sides' claims in Buttes Gas with his expressed concern over impact on neutrality, embarrassment in foreign relations, and inability to ascertain judicial or manageable standards. ${ }^{388}$

These considerations apply with particular force in Pinochet. As discussed at the outset, the United Kingdom had enjoyed cordial relations with the Pinochet regime and apparently acquiesced in his trip to the United Kingdom; the claim involved a dispute between two U.K. allies; and the claim involved a highly sensitive matter of Chilean domestic politics with serious implications for amnesties in other countries.

Because as a matter of separation of powers, such matters are entrusted to the foreign relations authority of the executive, I believe that the U.K. courts should have abstained from deciding Pinochet's habeas claim when presented. The courts should have dismissed it as non-justiciable or, perhaps, not ripe for adjudication. This would have relegated Pinochet to his rights under the Extradition Act, a procedure allowing the executive branch to make the determination on such matters as prior acquiescence, the competing claims of Chilean and Spanish allies, and the impact on national reconciliation efforts generally. Then, had extradition gone forward, the court could have reviewed Pinochet's sovereign immunity claim in accordance with a procedure explicitly authorized by the legislative branch.

384. Banco Nacional de Cube v. Sabbatino, 376 U.S. 398, 432 (1964).

385. Id. at 433.

386. Baker v. Carr, 369 U.S. 186, 211 (1962).

387. Id.

388. See Buttes Gas \& Oil Co., [1982] A.C. at 938. 